\title{
Obinutuzumab (GA101) for the Treatment of Chronic Lymphocytic Leukemia and Other B-Cell Non-Hodgkin's Lymphomas: A Glycoengineered Type II CD20 Antibody
}

\author{
Valentin Goede ${ }^{\mathrm{a}}$ Christian Klein ${ }^{\mathrm{b}}$ Stephan Stilgenbauer ${ }^{\mathrm{c}}$ \\ a German CLL Study Group, Department I of Internal Medicine, University Hospital Cologne, Germany; \\ ${ }^{\mathrm{b}}$ Roche Pharma Research and Early Development, Roche Innovation Center Zurich, Switzerland; \\ c Klinik für Innere Medizin III, Universitätsklinikum UIm, Germany
}

\section{Keywords}

Obinutuzumab - Monoclonal humanized antibodies .

Mode of action - Chronic lymphocytic leukemia .

Diffuse large B-cell lymphoma · Follicular lymphoma

\section{Summary}

Obinutuzumab (GA101) is a humanized, monoclonal type II CD20 antibody modified by glycoengineering. The glycoengineered Fc portion enhances the binding affinity to the FcyRIII receptor on immune effector cells, resulting in increased antibody-dependent cellular cytotoxicity and phagocytosis. In addition, the type II antibody binding characteristics of obinutuzumab to CD20 lead to an efficient induction of direct non-apoptotic cell death. Preclinical data demonstrated more efficient B-cell depletion in whole blood and superior antitumor activity in xenograft models of obinutuzumab as compared to the type I CD20 antibody rituximab. In previously untreated patients with chronic lymphocytic leukemia (CLL) and comorbidities, obinutuzumab plus chlorambucil increased response rates and prolonged progression-free survival compared with rituximab plus chlorambucil. Obinutuzumab had an acceptable and manageable safety profile, with infusion-related reactions during the first infusion as the most common adverse event. Further phase I/II clinical trials have also shown promising activity in other CD20-positive B-cell non-Hodgkin's lymphomas (NHL). Therefore, several clinical studies are planned or ongoing to investigate obinutuzumab with different combination partners in both untreated and relapsed/refractory patients with different B-cell NHL entities, which in addition to CLL include diffuse large B-cell lymphoma and follicular lymphoma.

\section{Therapeutic Need in CD20-Positive B-Cell Lymphomas}

The monoclonal type I antibody rituximab specifically targets the CD20 antigen expressed on the surface of mature and pre-Bcells. Rituximab in combination with chemotherapy prolonged survival times in many B-cell lymphomas, e.g. diffuse large B-cell lymphoma (DLBCL) $[1,2]$, chronic lymphocytic leukemia (CLL) [3], follicular lymphoma (FL), and mantle cell lymphoma (MCL) [4]. Most patients, however, eventually relapse and may become resistant to therapy [5]. Therefore, the goal of the development of new CD20 antibodies is to obtain improved properties such as a more efficient B-cell depletion to achieve increased clinical activity [6-8]. In this review, we elucidate the mode of action and present the clinical development of obinutuzumab (GA101, GAZYVA ${ }^{\mathrm{TM}}$ /

GAZYVARO $^{\mathrm{TM}}$, F. Hoffmann-La Roche, Basel, Switzerland). Following approval in the US in 2013, obinutuzumab in combination with chlorambucil has also been licensed in Europe since July 2014 for the treatment of adult patients with previously untreated CLL and with comorbidities making them unsuitable for full-dose fludarabine-based therapy.

\section{Structural Characteristics and Mode of Action}

\section{Obinutuzumab Is a Glycoengineered CD20 Antibody}

Obinutuzumab is a glycoengineered, humanized, monoclonal type II CD20 antibody of the IgG1 isotype [9] that was developed in an attempt to enhance both induction of immune effector cellmediated killing of tumor cells and direct cell death compared with rituximab. To increase antibody-dependent cellular cytotoxicity (ADCC) and phagocytosis (ADCP), binding affinity to the Fc $\gamma$ RIII receptor on immune effector cells was enhanced via a posttranslational glycoengineering process: the enzymatic equipment of the

\section{KARGER \\ Fax +497614520714} Information@Karger.com www.karger.com (c) 2015 S. Karger GmbH, Freiburg
$2296-5270 / 15 / 0384-0185 \$ 39.50 / 0$$\quad \begin{aligned} & \text { Karger } \\ & \text { Open access }\end{aligned}$ This is an Open Access article licensed under the terms of the Creative Commons Attribution-NonCommercial 3.0 Unported license

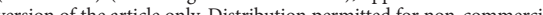
purposes only.
Prof. Dr. med. Stephan Stilgenbauer

Klinik für Innere Medizin III, Hämatologie, Onkologie, Palliativmedizin, Rheumatologie und Infektionskrankheiten

Universitätsklinikum Ulm

Albert-Einstein-Allee 23, 89081 Ulm, Germany

Stephan.Stilgenbauer@uniklinik-ulm.de 
Fig. 1. Glycoengineered structure and type II binding properties of obinutuzumab. A Glycoengineering by defucosylation of IgG oligosaccharides in the $\mathrm{Fc}$ region of obinutuzumab. In the $\mathrm{CHO}$ producer cells, more $\mathrm{N}$-acetylglucosamine (NAG) is assembled into oligosaccharides, which sterically prevents the addition of fucose to the carbohydrate attached to asparagine (Asn) 297 [7]. Adapted and reproduced with permission from [7]. B Hypothetical model of $\mathrm{CD} 20$ binding properties of type I and type II antibodies [8]. In contrast to intertetrameric CD20 binding of type I antibodies, intra-tetrameric binding of type II antibodies to CD20 does not lead to Fc $\gamma$ RIIb-mediated internalization of CD20 in lipid rafts. Adapted from [8].

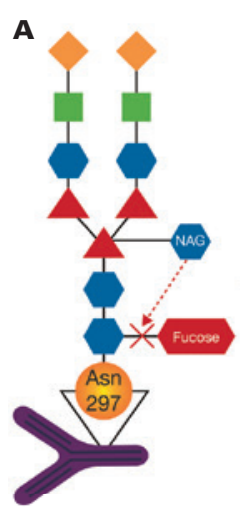

B

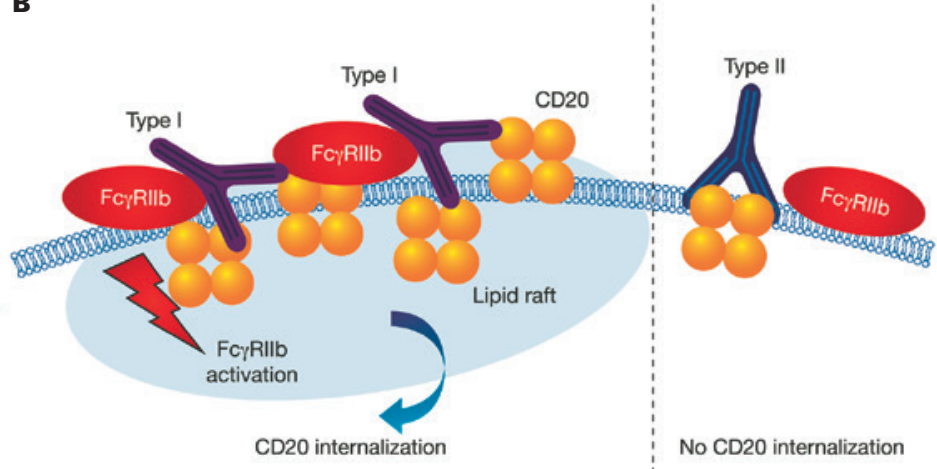

production cells enables the generation of an antibody glycovariant lacking fucosylation of the carbohydrate attached to the Fc region [9] (fig. 1 A). Indeed, in vitro Fc $\gamma$ RIII receptor affinity was shown to be considerably higher for obinutuzumab than for rituximab [9].

\section{$A D C C$}

The enhanced binding of obinutuzumab to Fc $\gamma$ RIII results in an increase in ADCC: the in vitro ADCC activity of obinutuzumab was 35-100 times higher than that of rituximab [9] or ofatumumab [10], and in contrast to rituximab, ADCC of obinutuzumab was neither blocked by physiological concentrations of unspecific IgG [9] nor by complement [11]. Notably, obinutuzumab was shown to abrogate inhibitory signals by inhibitory killer cell Ig-like receptor (KIR)/human leukocyte antigen (HLA) interactions [12]. In addition, combination studies with ibrutinib and idelalisib demonstrated that these kinase inhibitors had only minimal inhibitory impact on the immune effector function of obinutuzumab $[13,14]$.

\section{$A D C P$}

Obinutuzumab recruits phagocytic cells such as monocytes, neutrophils, and dendritic cells via $\mathrm{Fc}_{\mathrm{c}} \mathrm{Fc} \gamma \mathrm{R}$ interactions. Therefore, the glycoengineered structure of obinutuzumab not only augments ADCC, but also increases the phagocytosis and cytotoxic activity effected by monocytes and macrophages [15] through Fc $\gamma$ RIIIa as well as by neutrophils through Fc $\gamma$ RIIIb [16].

\section{Obinutuzumab Is a Type II CD20 Antibody}

Antibodies against CD20 can be grouped into 2 major classes referred to as type I and type II CD20 antibodies [8] (table 1). In in vitro assays, homotypic aggregation associated with direct cell death is a characteristic feature of type II antibodies. Rituximab and ofatumumab belong to the group of type I antibodies, while obinutuzumab is a type II antibody derived by humanization of the murine B-Ly1 antibody, which induces homotypic cell aggregation to a certain extent [9]. Obinutuzumab was identified in in vitro assays as an antibody variant that effectively induced direct cell death of B-cells [9]. Compared with the murine sequence, leucine 11 was substituted by valine in obinutuzumab, resulting in an elbow angle between the antigen-binding arms (Fab) that is nearly $30^{\circ}$ wider
Table 1. Differences between type I and type II CD20 antibodies and examples (adapted from $[7,8,51]$ )

\begin{tabular}{ll}
\hline Type I CD20 antibodies & Type II CD20 antibodies \\
\hline CD20 accumulation in lipid rafts & no CD20 accumulation in lipid rafts \\
High CDC & low/no CDC \\
ADCC & ADCC \\
ADCP & ADCP \\
Full CD20 binding capacity & half maximal CD20 binding capacity \\
CD20 downregulation & no CD20 downregulation \\
$\quad$ Fc $\gamma$ RIIb-mediated $)$ & \\
Weak/no homotypic cell & homotypic cell aggregation \\
$\quad$ aggregation & \\
Direct cell death & stronger induction of direct cell death, \\
Rituximab, ocrelizumab, & caspase-independent \\
$\quad$ ofatumumab, veltuzumab, & obinutuzumab, tositumomab
\end{tabular}

$\mathrm{CDC}=$ Complement-dependent cytotoxicity; ADCC = antibody-dependent cellular cytotoxicity; ADCP = antibody-dependent cellular phagocytosis.

than in type I antibodies [17]. In addition, obinutuzumab binds $\mathrm{CD} 20$ in a different orientation than type I antibodies, i.e. rotated by $90^{\circ}$ around its middle axis and also tilted $70^{\circ}$ towards the CD20 epitope [17]. Another typical feature of type II antibodies is that only half as many antibodies bind per B-cell compared with type I antibodies. Presumably, the different binding topology of type II antibodies causes the $2 \mathrm{Fab}$ arms to bind within a single CD20 tetramer, while type I antibodies are assumed to bind different CD20 tetramers with each Fab arm [8]. Upon binding of rituximab, the CD20 antibody complex can be internalized and degraded, resulting in reduced effector cell recruitment and antibody half-life [18]. Type I CD20antibody-mediated CD20 internalization appears to be dependent on binding to the inhibitory Fc $\gamma$ RIIb receptor expressed on B-cells in a cis fashion [19]. In contrast, type II CD20 antibodies show only minimal CD20 internalization [20]. Figure $1 \mathrm{~B}$ depicts a model in which the special binding properties of type II antibodies prevent interaction with Fc $\gamma$ RIIb, thus also preventing the accumulation of CD20 in lipid rafts and downregulation of CD20 surface expression, as compared to type I antibodies. 


\section{Direct Non-Apoptotic Cell Death}

As a consequence of homotypic cell aggregation, obinutuzumab triggers direct non-apoptotic cell death $[21,22]$ which is associated with actin rearrangement, lysosomal cathepsin release, and the generation of reactive oxygen species via nicotinamide adenine dinucleotide phosphate (NADPH) oxidase. Because of the absence of characteristic hallmarks of apoptosis such as caspase dependency or BCL2 expression, this type of cell death could bypass mechanisms of apoptotic resistance [23]. Furthermore, direct cell death is induced independently of $\mathrm{Fc}-\mathrm{Fc} \gamma \mathrm{R}$ interaction. Therefore, obinutuzumab could also be an improved therapy option for patients with impaired Fc function, e.g. patients with low-affinity Fc $\gamma$ RIIIa variants [24], as well as patients with effector cell saturation, exhaustion, or depletion.

\section{Complement-Dependent Cytotoxicity}

Since obinutuzumab does not accumulate CD20 molecules in lipid rafts, no Fc clustering in lipid rafts occurs, which leads to decreased activation of complement-dependent cytotoxicity (CDC) via C1q. Accordingly, obinutuzumab demonstrated a $>10-1,000$ fold lower CDC activity than rituximab and ofatumumab [10]. $\mathrm{CDC}$ is thus not considered a relevant clinical mechanism of obinutuzumab activity.

\section{Superior Antitumor Activity of Obinutuzumab in Preclinical Models}

In in vitro and in vivo studies, obinutuzumab was shown to be superior to rituximab regarding both direct as well as effector cellmediated cytotoxicity: obinutuzumab demonstrated a more efficient B-cell depletion in whole blood in vitro/ex vivo $[9,10]$, and superior antitumor activity in xenograft models, even in rituximab-refractory tumors $[9,10,25,26]$. In particular, clinically relevant doses of obinutuzumab induced complete remission of SUDHL4 DLBCL tumors, while an identical dose of rituximab merely inhibited tumor progression $[9,10]$. In primates, obinutuzumab achieved B-cell depletion superior to rituximab in lymphoid tissue, including lymph nodes and spleen [9]. Combination studies showed that obinutuzumab demonstrates enhanced activity in combination with chemotherapies such as chlorambucil, fludarabine, and bendamustine, resulting in superior antitumor efficacy compared with the respective combination with rituximab [26]. Furthermore, antitumor efficacy can be enhanced by combining obinutuzumab with the Bcl-2-selective inhibitor GDC-199 [27] or the MDM2-selective inhibitor RG7388 [28].

\section{Clinical Trials in B-Cell NHL}

\section{Phase I/II}

In the phase I part of the GAUGUIN study (BO20999) $[29,30]$, 21 patients with relapsed/refractory indolent NHL received escalating doses of obinutuzumab monotherapy over 821 -day cycles [29].
The phase I part of the GAUSS trial (BO21003) was conducted with 22 patients with relapsed NHL, including 5 patients with CLL [31]. Patients were given escalating doses of obinutuzumab once weekly over 4 weeks. These 2 phase I trials reported overall response rates (ORR) of $32-43 \%$. No dose-limiting toxicity was observed, and infusion-related reactions (IRR) were the most common adverse events (AE) [29, 31]. Similarly, neither an obinutuzumab-associated dose-limiting toxicity nor any unexpected $\mathrm{AE}$ were seen in the phase Ib GAUDI study (BO21000), in which patients with relapsed/refractory FL were treated with obinutuzumab in combination with either $\mathrm{CHOP}$ (cyclophosphamide, doxorubicine, vincristine, prednisone) or FC (fludarabine, cyclophosphamide) [32]; also no unexpected $\mathrm{AE}$ were reported, including in previously untreated patients with FL, who were given obinutuzumab plus either CHOP or bendamustine [33].

The phase II stage of the GAUGUIN study included 40 patients with relapsed/refractory indolent NHL [34] and 40 patients with relapsed/refractory DLBCL or MCL [35]. Among the 2 dose groups that were tested, particularly the higher dose group $(1,600 / 800 \mathrm{mg}$ obinutuzumab) showed promising efficacy results and an acceptable safety profile. The randomized controlled phase II GAUSS trial compared obinutuzumab or rituximab monotherapies followed by maintenance therapies in 175 patients with relapsed indolent NHL, including 149 patients with FL [36]. Based on investigator assessment, higher ORR were achieved with obinutuzumab than with rituximab ( 43.2 vs. $35.6 \%$ in the overall population, 43.2 vs. $38.7 \%$ in patients with FL). No difference was found regarding the secondary end point progression-free survival (PFS); however, the trial was not powered to detect a difference in PFS. Obinutuzumab was well tolerated, although IRR occurred more frequently in the obinutuzumab arm.

Dose-finding studies such as GAUGUIN demonstrated that upon administration of a 1,600/800 $\mathrm{mg}$ dose of obinutuzumab, plasma concentrations increased more rapidly than with lower doses, leading to an early steady state indicative of CD20 target saturation [35]. Based on both clinical data and pharmacokinetic simulations, a fixed dose of 1,000 mg obinutuzumab on days 1,8 , and 15 of the first 21day cycle and on day 1 of subsequent cycles was selected as the dose to achieve adequate exposure levels in a similarly rapid manner with less interindividual variability in phase III trials [37].

In the phase II GATHER study (GAO4915g), 80 untreated patients with advanced DLBCL were treated with 6 cycles of a CHOP regimen, plus 8 cycles of obinutuzumab dosed as described above [38].

Details on treatment regimens and results of the clinical studies described in this section are listed in table 2 .

\section{Clinical Trials in CLL}

\section{Phase I/II}

For the 13 patients with relapsed/refractory CLL in the phase I part of the GAUGUIN study, an ORR of $62 \%$ was reported at the end of treatment [30]. For the 20 patients in the phase II part of GAUGUIN, a lower ORR of $30 \%$ was reached, which may be due to a higher baseline tumor burden resulting in lower exposure to 


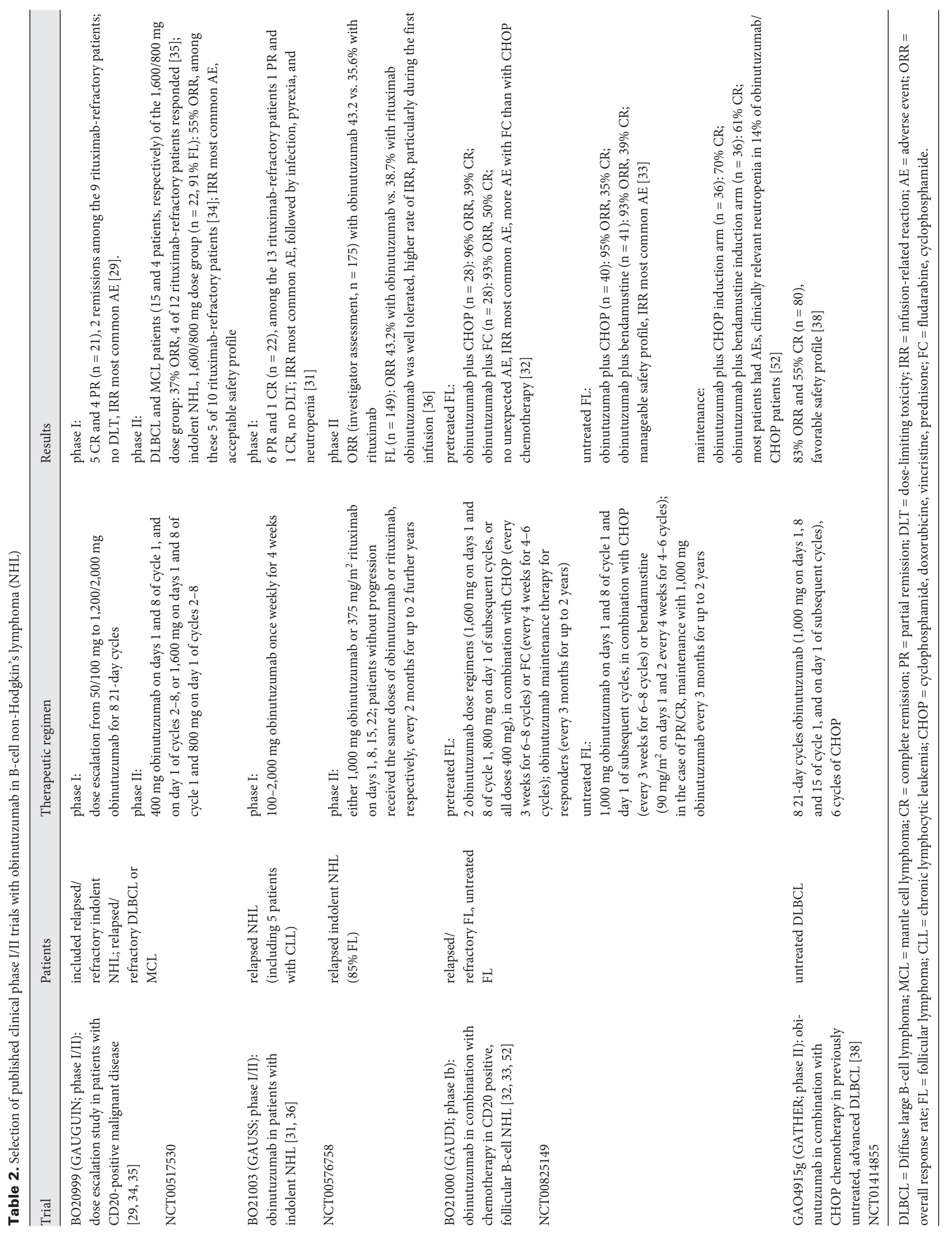


Table 3. Selection of published clinical phase I/II studies with obinutuzumab in chronic lymphocytic leukemia (CLL)

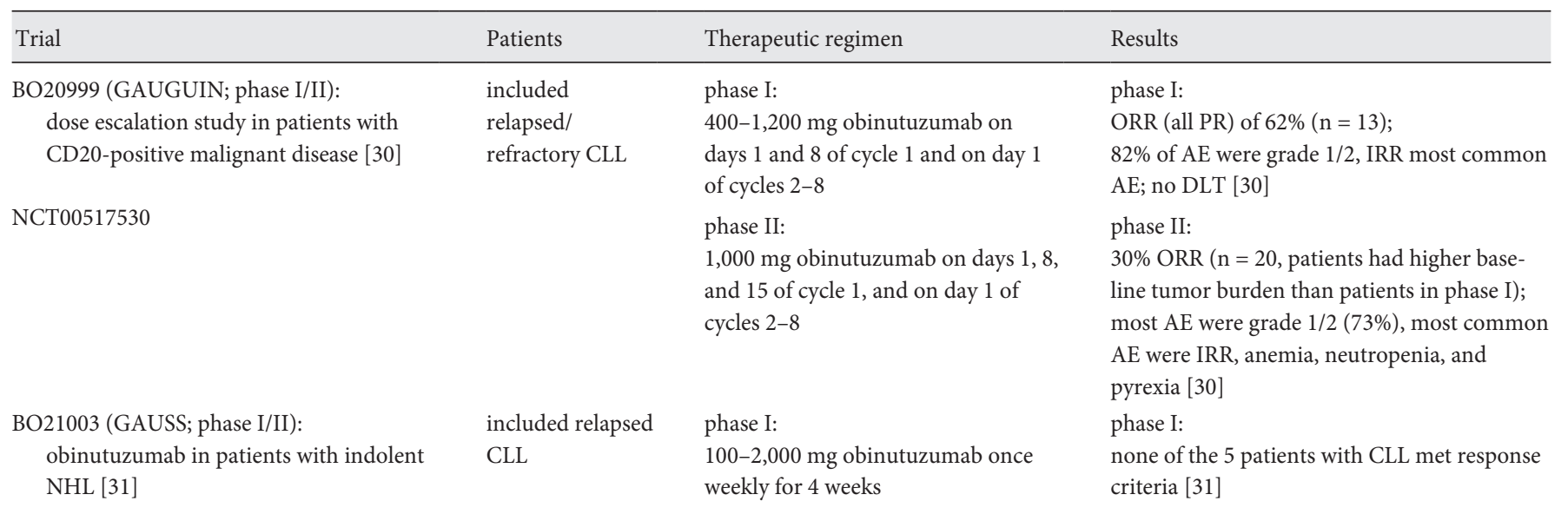

\section{NCT00576758 \\ GAO4768g (GAGE; phase II): obinutuzumab $1,000 \mathrm{mg}$ vs. $2,000 \mathrm{mg}$ in patients with previously untreated CLL [39]}

\section{NCT01414205}

GAO4779g (GALTON; phase Ib): obinutuzumab in combination with chemotherapy in patients with previously untreated CLL [40]

NCT01300247

\section{untreated CLL}

$$
\begin{aligned}
& 1,000 \mathrm{mg} \text { obinutuzumab: } \\
& 100 \mathrm{mg} \text { on day } 1,900 \mathrm{mg} \text { on day } 2 \text {, } \\
& 1,000 \mathrm{mg} \text { on days } 8 \text { and } 15 \text { of cycle } 1 \text {; } \\
& 1,000 \mathrm{mg} \text { on day } 1 \text { of cycles } 2-8 \text {; } \\
& 2,000 \mathrm{mg} \text { obinutuzumab: } \\
& 100 \mathrm{mg} \text { on day } 1,900 \mathrm{mg} \text { on day } 2 \text {, } \\
& 1,000 \mathrm{mg} \text { on day } 3,2,000 \mathrm{mg} \text { on days } \\
& 8 \text { and } 15 \text { of cycle } 1 ; 2,000 \mathrm{mg} \text { on day } 1 \\
& \text { of cycles } 2-8 \\
& 100 \mathrm{mg} \text { obinutuzumab on day } 1,900 \\
& \text { mg on day } 2,1,000 \mathrm{mg} \text { on days } 8 \text { and } \\
& 15 \text { of cycle } 1 ; 1,000 \mathrm{mg} \text { on day } 1 \text { of } \\
& \text { cycles } 2-8 \text {; in combination with } \\
& \text { either FC or bendamustine }
\end{aligned}
$$

untreated CLL $\quad 100 \mathrm{mg}$ obinutuzumab on day 1,900
$49 \%$ ORR in the $1,000 \mathrm{mg}$ group $(\mathrm{n}=41)$ and $67 \%$ ORR in the $2,000 \mathrm{mg}$ group $(\mathrm{n}=39)$; no unexpected AE [39]

obinutuzumab plus FC ( $\mathrm{n}=21)$ : ORR 62\%; obinutuzumab plus bendamustine $(n=20)$ : ORR $90 \%$;

safety profile similar to standard immunochemotherapies, with neutropenia the most common $\geq$ grade $3 \mathrm{AE}$ [40]

ORR = Overall response rate; $\mathrm{PR}=$ partial remission; $\mathrm{AE}=$ adverse event; IRR = infusion-related reaction; DLT = dose-limiting toxicity; NHL = non-Hodgkin's lymphoma; FC = fludarabine, cyclophosphamide.

treatment [30]. None of the 5 patients with CLL in the phase I part of the GAUSS trial met the criteria for response [31].

In another phase II study called GAGE (GAO4768g), which included 80 patients with previously untreated CLL and compared 2 dosing regimens of obinutuzumab monotherapy, a higher ORR was demonstrated in the $2,000 \mathrm{mg}$ group (67 vs. $49 \%$ ) compared with the 1,000 mg group [39].

In the GALTON trial (GAO4779g; phase Ib), 41 patients with previously untreated CLL received obinutuzumab in combination with either FC or bendamustine [40]. The data showed that these combinations have clinical activity, with grade $3 / 4$ neutropenia and infections in 29 and $19 \%$ of the patients in the obinutuzumab plus FC arm and in 50 and $5 \%$ of the patients in the obinutuzumab plus bendamustine arm, respectively.

Table 3 provides an overview of the published trials in CLL, as discussed in this section.

\section{Phase III Study: CLL11}

The randomized controlled phase III study CLL11 (BO21004) [41] enrolled 781 patients with previously untreated CLL (median age 73 years) and relevant comorbidity indicated by a Cumulative
Illness Rating Scale (CIRS) score $>6$ and/or creatinine clearance of $30-69 \mathrm{ml} / \mathrm{min}$. The study compared obinutuzumab plus chlorambucil with rituximab plus chlorambucil and chlorambucil alone. Patients received 628 -day cycles of either chlorambucil $(0.5 \mathrm{mg} / \mathrm{kg}$ on days 1 and 15), obinutuzumab (1,000 mg on days 1,8 , and 15 of cycle 1 , and on day 1 of cycles 2-6) plus chlorambucil or rituximab $\left(375 \mathrm{mg} / \mathrm{m}^{2}\right.$ on day 1 of cycle $1,500 \mathrm{mg} / \mathrm{m}^{2}$ on day 1 of cycles $2-6$ ) plus chlorambucil. In the arms comparing obinutuzumab plus chlorambucil vs. rituximab plus chlorambucil, the administered median cumulative doses of antibodies were $8,000 \mathrm{mg}$ of obinutuzumab and 5,106 mg of rituximab, respectively.

Obinutuzumab plus chlorambucil was superior to rituximab plus chlorambucil in terms of PFS (median PFS 26.7 vs. 15.2 months; hazard ratio (HR) 0.39 ; $95 \%$ confidence interval (CI) 0.31 0.49 ; $\mathrm{p}<0.001$ ), complete response (20.7 vs. $7.0 \%$ ), and rate of negative testing for minimal residual disease, both in peripheral blood (37.7 vs. $3.3 \%$ ) and bone marrow (19.5 vs. $2.6 \%$ ) (fig. 2). After a median observation time of 19 months, no significant difference in overall survival was observed (HR for death 0.66 ; 95\% CI $0.41-$ 1.06; $\mathrm{p}=0.08$ ). Obinutuzumab plus chlorambucil did prolong overall survival, however, when compared to chlorambucil alone 
A

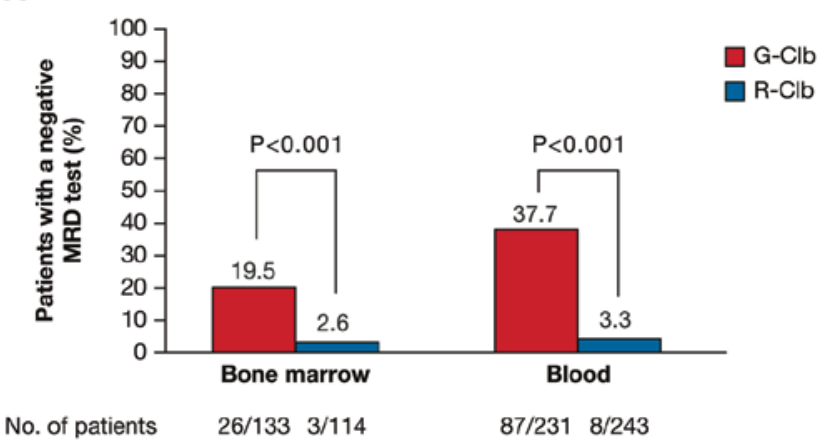

B

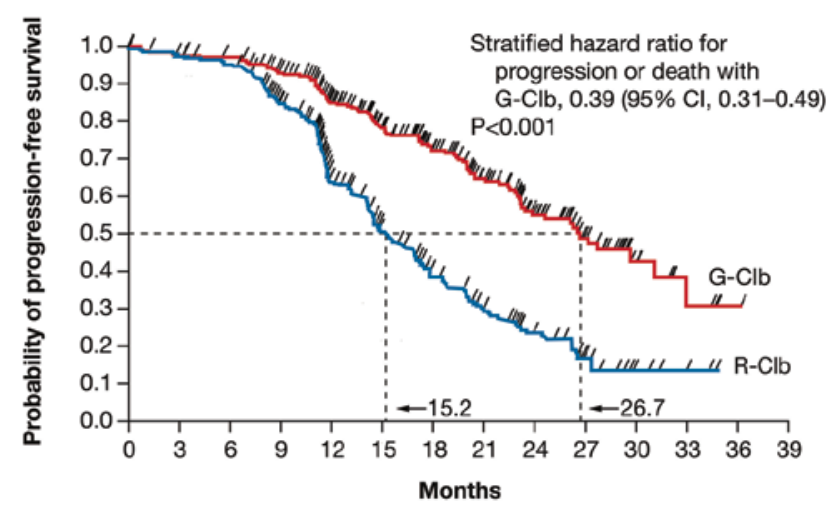

No. at risk

$\begin{array}{lllllllllllllll}\text { G-Clb } & 333 & 307 & 302 & 278 & 213 & 156 & 122 & 93 & 60 & 34 & 12 & 4 & 1 & 0\end{array}$

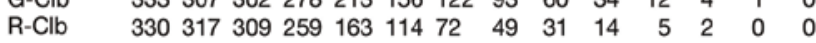

Fig. 2. Molecular response and progression-free survival with obinutuzumab plus chlorambucil versus rituximab plus chlorambucil (from [41]; Copyright ${ }^{\circledR}$ 2014 Massachusetts Medical Society, reprinted with permission). A Molecular response. B Progression-free survival. p values were calculated with the use of a stratified log-rank test. MRD $=$ Minimal residual disease; G-Clb = obinutuzumab plus chlorambucil; $\mathrm{R}-\mathrm{Clb}=$ rituximab plus chlorambucil.

(HR for death $0.41 ; 95 \%$ CI $0.23-0.74 ; \mathrm{p}=0.002$ ). A recent update with approximately 1 year of additional observation time showed an even better improvement in PFS with obinutuzumab plus chlorambucil (median PFS 29.2 vs. 15.4 months with rituximab plus chlorambucil, HR for death $0.40,95 \%$ CI $0.33-0.50, \mathrm{p}<0.001$ ) and confirmed the overall survival benefit of obinutuzumab plus chlorambucil over chlorambucil monotherapy (HR for death $0.47,95 \%$ CI $0.29-0.76, p=0.0014$ ). No statistically significant overall survival benefit for obinutuzumab plus chlorambucil over rituximab plus chlorambucil could be demonstrated so far (HR for death $0.70,95 \%$ CI $0.47-1.02, \mathrm{p}=0.0632$ ), although these overall survival data are still immature [42].AE occurred more frequently with obinutuzumab plus chlorambucil than with chlorambucil alone or rituximab plus chlorambucil, primarily including IRR (the most common $\mathrm{AE}$ in $66 \%$ of the patients), neutropenia, and thrombocytopenia, but the risk of infection was not increased. IRR frequency was high during the first infusion of obinutuzumab (20\% grade $3 / 4$ IRR, no deaths), but considerably lower during subsequent infusions ( $0 \%$ grade 3 or 4 IRR). Rapid and profound B-cell depletion and faster recruitment and activation of immune effector cells by obinutuzumab with subsequent cytokine release may possibly explain the more frequent and severe IRR during the first infusion with obinutuzumab [41]. Of note, preliminary data indicate a correlation between CD20 surface expression on CLL cells as well as Fc $\gamma$ RIII polymorphisms and the risk of developing any grade of IRR with the first infusion of rituximab or obinutuzumab [43].

Based on these data, obinutuzumab has recently been granted approval in Europe in combination with chlorambucil chemotherapy for the treatment of adult patients with previously untreated CLL and comorbidities making them unsuitable for full-dose fludarabine-based therapy.

\section{Perspectives}

Ongoing phase III studies investigate obinutuzumab as compared with rituximab in B-cell NHL entities other than CLL and in combination with other chemotherapy regimens. The phase III trial GOYA (BO21005, NCT01287741) compares the combination of $\mathrm{CHOP}$ plus obinutuzumab with $\mathrm{CHOP}$ plus rituximab in previously untreated DLBCL, and GALLIUM (BO21223, NCT01332968; phase III) tests obinutuzumab vs. rituximab in combination with different chemotherapies, i.e. CHOP, CVP (cyclophosphamide, vincristine, prednisone), and bendamustine, followed by maintenance with obinutuzumab/rituximab, in patients with untreated indolent NHL (FL or marginal zone lymphoma). Rituximab-refractory patients with indolent NHL were treated with obinutuzumab plus bendamustine or bendamustine alone in the phase III GADOLIN study (GAO4753g, NCT01059630). Due to superiority of the obinutuzumab/bendamustine combination at the preplanned interim analysis, the study was terminated prior to the protocol-specified final analysis [44]. The phase IIIb safety trial GREEN (MO28543, NCT01905943) investigates obinutuzumab alone or in combination with FC, bendamustine, or chlorambucil both in previously untreated and relapsed/refractory CLL; preliminary data were in line with the known safety profile of obinutuzumab [45].

Furthermore, obinutuzumab is an especially interesting option for the assessment of chemotherapy-free combination therapies due to its optimized effector functions. Preclinical data suggest that effective combinations with targeted anticancer agents are possible and that synergistic effects can be expected, e.g. with the Bcl-2 inhibitor venetoclax (ABT-199/GDC-0199) [27], MDM2 inhibitors RG7112 and RG7388 [28], as well as the proteasome inhibitor bortezomib [46]. Preclinical data demonstrated that the kinase inhibitor ibrutinib interferes with the ADCC-related effector function of rituximab through inhibition of interleukin-2 inducible tyrosine kinase [47]. However, minimal interference of idelalisib and ibrutinib was observed with the immune effector function of obinutuzumab compared with rituximab most likely due to the direct cell death induction and stronger $\mathrm{F}_{\mathrm{c}} \mathrm{R}$ R signaling, supporting the clinical testing of these combinations [13, 14, 48]. First safety data from a phase $1 \mathrm{~b}$ trial investigating obinutuzumab plus venetoclax in CLL was encouraging [49]. Corresponding clinical studies exploring 
chemotherapy-free or -reduced treatments in CLL are currently being initiated including several trials of the German CLL Study Group (GCLLSG). A series of phase II GCLLSG studies (all-comers, i.e. both untreated and treated, and both fit and comorbid patients) will sequentially evaluate bendamustine, obinutuzumab, and either ibrutinib (BIG), venetoclax (BAG), or idelalisib (BCG). Furthermore, following the recently published phase Ib data of the GALEN study, which showed that oral lenalidomide plus obinutuzumab was well tolerated and effective in patients with relapsed or refractory FL [50], the ongoing phase II part of the study will assess obinutuzumab in combination with lenalidomide in patients with relapsed/refractory follicular and aggressive B-cell lymphomas (DLBCL and MCL).

\section{Acknowledgement}

The authors would like to thank Physicians World Europe for providing medical writing assistance for the preparation of this manuscript, supported by Roche Pharma AG, Grenzach-Wyhlen, Germany.

\section{Disclosure Statement}

Valentin Goede: Roche: speaker honoraria, advisory board, research funding, travel grants; Mundipharma: speaker honoraria, advisory board, research funding, GSK: speaker honoraria. Christian Klein: Roche: employment, equity. Stephan Stilgenbauer: honoraria and research funding from AbbVie, Celgene, Genentech, Gilead, GSK, Janssen, Mundipharma, Roche.

\section{References}

$D_{1}$ Coiffier B, Lepage E, Briere J, Herbrecht R, Tilly H, Bouabdallah R, Morel P, Van Den Neste E, Salles G, Gaulard P, Reyes F, Lederlin P, Gisselbrecht C: CHOP chemotherapy plus rituximab compared with chop alone in elderly patients with diffuse large-B-cell lymphoma. N Engl J Med 2002;346:235-242.

2 Pfreundschuh M, Trumper L, Osterborg A, Pettengell R, Trneny M, Imrie K, Ma D, Gill D, Walewski J, Zinzani PL, Stahel R, Kvaloy S, Shpilberg O, Jaeger U, Hansen M, Lehtinen T, Lopez-Guillermo A, Corrado C, Scheliga A, Milpied N, Mendila M, Rashford M, Kuhnt E, Loeffler M; MabThera International Trial Group: CHOP-like chemotherapy plus rituximab versus CHOP-like chemotherapy alone in young patients with good-prognosis diffuse large-B-cell lymphoma: a randomised controlled trial by the MabThera International Trial (MInT) Group. Lancet Oncol 2006;7:379-391.

$\checkmark 3$ Hallek M, Fischer K, Fingerle-Rowson G, Fink AM, Busch R, Mayer J, Hensel M, Hopfinger G, Hess G, von Grunhagen U, Bergmann M, Catalano J, Zinzani PL, Caligaris-Cappio F, Seymour JF, Berrebi A, Jager U, Cazin B, Trneny M, Westermann A, Wendtner CM, Eichhorst BF, Staib P, Buhler A, Winkler D, Zenz T, Bottcher S, Ritgen M, Mendila M, Kneba M, Dohner H, Stilgenbauer S, International Group of I, German Chronic Lymphocytic Leukaemia Study G: Addition of rituximab to fludarabine and cyclophosphamide in patients with chronic lymphocytic leukaemia: a randomised, open-label, phase 3 trial. Lancet 2010;376:1164-1174.

4 Schulz H, Bohlius J, Skoetz N, Trelle S, Kober T, Reiser M, Dreyling M, Herold M, Schwarzer G, Hallek M, Engert A: Chemotherapy plus rituximab versus chemotherapy alone for B-cell non-Hodgkin's lymphoma. Cochrane Database Syst Rev 2007:CD003805.

5 Maloney DG: Immunotherapy for non-Hodgkin's lymphoma: monoclonal antibodies and vaccines. J Clin Oncol 2005;23:6421-6428.

6 Gagez AL, Cartron G: New anti-CD20 monoclonal antibodies: which is the best? Leuk Lymphoma 2015;56: $1-2$.

7 Klein C, Bacac M, Umana P, Wenger M: Obinutuzumab $\left(\right.$ GAZYVA $\left.^{\circledR}\right)$, a novel glycoengineered type II CD20 antibody for the treatment of chronic lymphocytic leukemia and non-Hodgkin's lymphoma; in Dübel S, Reichert JM (eds): Handbook of Therapeutic Antibodies. Weinheim, Wiley-VCH Verlag GmbH \& Co. KGaA, 2014.

$>$ Klein C, Lammens A, Schafer W, Georges G, Schwaiger M, Mossner E, Hopfner KP, Umana P, Niederfellner G: Epitope interactions of monoclonal antibodies targeting CD20 and their relationship to functional properties. MAbs 2013;5:22-33.
9 Mössner E, Brunker P, Moser S, Puntener U, Schmidt C, Herter S, Grau R, Gerdes C, Nopora A, van Puijenbroek E, Ferrara C, Sondermann P, Jager C, Strein P, Fertig G, Friess T, Schull C, Bauer S, Dal Porto J, Del Nagro C, Dabbagh K, Dyer MJ, Poppema S, Klein C, Umana P: Increasing the efficacy of CD20 antibody therapy through the engineering of a new type II antiCD20 antibody with enhanced direct and immune effector cell-mediated B-cell cytotoxicity. Blood 2010; 115:4393-4402.

10 Herter S, Herting F, Mundigl O, Waldhauer I, Weinzierl T, Fauti T, Muth G, Ziegler-Landesberger D, Van Puijenbroek E, Lang S, Duong MN, Reslan L, Gerdes CA, Friess T, Baer U, Burtscher H, Weidner M, Dumontet C, Umana P, Niederfellner G, Bacac M, Klein C: Preclinical activity of the type II CD20 antibody GA101 (obinutuzumab) compared with rituximab and ofatumumab in vitro and in xenograft models. Mol Cancer Ther 2013;12:2031-2042.

11 Kern DJ, James BR, Blackwell S, Gassner C, Klein C, Weiner GJ: GA101 induces NK-cell activation and antibody-dependent cellular cytotoxicity more effectively than rituximab when complement is present. Leuk Lymphoma 2013;54:2500-2505.

12 Terszowski G, Klein C, Stern M: KIR/HLA interactions negatively affect rituximab- but not GA101 (obinutuzumab)-induced antibody-dependent cellular cytotoxicity. J Immunol 2014;192:5618-5624.

13 Herter S, Palazzo A, Bacac M, Grosmaire L, Frey C, Pflanz S, Liu J, Tannheimer S, Umana P, Klein C, Queva C: The PI3K delta selective inhibitor idelalisib minimally interferes with immune effector function and $\mathrm{B}$ cell depletion mediated by obinutuzumab (GA101) and rituximab. Blood (ASH Ann Meet Abstr) 2014;124:3342.

14 Herter S, Sagiv-Barfi I, Chester C, Sadaram M, Hebb J, Czerwinski DK, Rajasekaran N, Bacac M, Umana P, Levy R, Klein C, Kohrt HE: Obinutuzumab (GA101) is less prone to antagonism of immune effector function by ibrutinib than rituximab in vitro and in vivo. Blood (ASH Ann Meet Abstr) 2014;124:1765.

15 Herter S, Birk MC, Klein C, Gerdes C, Umana P, Bacac $\mathrm{M}$ : Glycoengineering of therapeutic antibodies enhances monocyte/macrophage-mediated phagocytosis and cytotoxicity. J Immunol 2014;192:2252-2260.

16 Golay J, Da Roit F, Bologna L, Ferrara C, Leusen JH, Rambaldi A, Klein C, Introna M: Glycoengineered CD20 antibody obinutuzumab activates neutrophils and mediates phagocytosis through CD16B more efficiently than rituximab. Blood 2013;122:3482-3491.
17 Niederfellner G, Lammens A, Mundigl O, Georges GJ, Schaefer W, Schwaiger M, Franke A, Wiechmann K, Jenewein S, Slootstra JW, Timmerman P, Brannstrom A, Lindstrom F, Mossner E, Umana P, Hopfner KP, Klein C: Epitope characterization and crystal structure of GA101 provide insights into the molecular basis for type I/II distinction of CD20 antibodies. Blood 2011; 118:358-367.

18 Beers SA, French RR, Chan HT, Lim SH, Jarrett TC, Vidal RM, Wijayaweera SS, Dixon SV, Kim H, Cox KL, Kerr JP, Johnston DA, Johnson PW, Verbeek JS, Glennie MJ, Cragg MS: Antigenic modulation limits the efficacy of anti-CD20 antibodies: implications for antibody selection. Blood 2010;115:5191-5201.

19 Lim SH, Vaughan AT, Ashton-Key M, Williams EL, Dixon SV, Chan HT, Beers SA, French RR, Cox KL, Davies AJ, Potter KN, Mockridge CI, Oscier DG, Johnson PW, Cragg MS, Glennie MJ: Fc gamma receptor IIb on target $\mathrm{B}$ cells promotes rituximab internalization and reduces clinical efficacy. Blood 2011;118:2530-2540.

20 Beers SA, Chan CH, French RR, Cragg MS, Glennie MJ: CD20 as a target for therapeutic type I and II monoclonal antibodies. Semin Hematol 2010;47:107-114.

-21 Ivanov A, Beers SA, Walshe CA, Honeychurch J, Alduaij W, Cox KL, Potter KN, Murray S, Chan CH, Klymenko T, Erenpreisa J, Glennie MJ, Illidge TM, Cragg MS: Monoclonal antibodies directed to CD20 and HLA-DR can elicit homotypic adhesion followed by lysosome-mediated cell death in human lymphoma and leukemia cells. J Clin Invest 2009;119:2143-2159.

22 Alduaij W, Ivanov A, Honeychurch J, Cheadle EJ, Potluri S, Lim SH, Shimada K, Chan CH, Tutt A, Beers SA, Glennie MJ, Cragg MS, Illidge TM: Novel type II anti-CD20 monoclonal antibody (GA101) evokes homotypic adhesion and actin-dependent, lysosome-mediated cell death in B-cell malignancies. Blood 2011; 117:4519-4529.

23 Illidge T, Cheadle EJ, Donaghy C, Honeychurch J: Update on obinutuzumab in the treatment of B-cell malignancies. Expert Opin Biol Ther 2014;14:1507-1517.

24 Cartron G, Dacheux L, Salles G, Solal-Celigny P, Bardos P, Colombat P, Watier H: Therapeutic activity of humanized anti-CD20 monoclonal antibody and polymorphism in IgG Fc receptor FcgammaRIIIa gene. Blood 2002;99:754-758.

25 Dalle S, Reslan L, Besseyre de Horts T, Herveau S, Herting F, Plesa A, Friess T, Umana P, Klein C, Dumontet C: Preclinical studies on the mechanism of action and the anti-lymphoma activity of the novel anti-CD20 antibody GA101. Mol Cancer Ther 2011;10:178-185. 
26 Herting F, Friess T, Bader S, Muth G, Holzlwimmer G, Rieder N, Umana P, Klein C: Enhanced anti-tumor activity of the glycoengineered type II CD20 antibody obinutuzumab (GA101) in combination with chemotherapy in xenograft models of human lymphoma. Leuk Lymphoma 2014;55:2151-5160.

27 Sampath D, Herter S, Herting F, Ingalla E, Nannini M, Bacac M, Fairbrother WJ, Klein C: Combination of the glycoengineered type II CD20 antibody obinutuzumab (GA101) and the novel BCL-2 selective inhibitor GDC-0199 results in superior in vitro and in vivo antitumor activity in models of B-cell malignancies. Blood (ASH Ann Meet Abstr) 2013;122:4412.

28 Herting F, Herter S, Friess T, Lehmann C, Bacac M, Dangl M, Klein C: Combination of the glycoengineered type II CD20 antibody obinutuzumab (GA101) and the MDM2 selective antagonist RG7388 results in superior anti-tumor activity. Blood (ASH Ann Meet Abstr) 2014;124:1780.

29 Salles G, Morschhauser F, Lamy T, Milpied N, Thieblemont C, Tilly H, Bieska G, Asikanius E, Carlile D, Birkett J, Pisa P, Cartron G: Phase 1 study results of the type ii glycoengineered humanized anti-CD20 monoclonal antibody obinutuzumab (GA101) in B-cell lymphoma patients. Blood 2012;119:5126-5132.

30 Cartron G, de Guibert S, Dilhuydy MS, Morschhauser F, Leblond V, Dupuis J, Mahe B, Bouabdallah R, Lei G, Wenger M, Wassner-Fritsch E, Hallek M: Obinutuzumab (GA101) in relapsed/refractory chronic lymphocytic leukemia: final data from the phase $1 / 2 \mathrm{GAU}$ GUIN study. Blood 2014;124:2196-2202.

- 31 Sehn LH, Assouline SE, Stewart DA, Mangel J, Gascoyne RD, Fine G, Frances-Lasserre S, Carlile DJ, Crump M: A phase 1 study of obinutuzumab induction followed by 2 years of maintenance in patients with relapsed CD20-positive B-cell malignancies. Blood 2012;119:5118-5125.

32 Radford J, Davies A, Cartron G, Morschhauser F, Salles G, Marcus R, Wenger M, Lei G, Wassner-Fritsch E, Vitolo U: Obinutuzumab (GA101) plus CHOP or FC in relapsed/refractory follicular lymphoma: results of the GAUDI study (BO21000). Blood 2013;122: 1137-1143.

33 Dyer MJS, Grigg A, González M, Dreyling M, Rule SA, Lei G, Wassner-Fritsch E, Wenger MK, Marlton P: Obinutuzumab (GA101) in combination with cyclophosphamide, doxorubicin, vincristine and prednisone (CHOP) or bendamustine in patients with previously untreated follicular lymphoma (FL): results of the phase Ib GAUDI study (BO21000). Blood (ASH Ann Meet Abstr) 2012;120:3686.

34 Salles GA, Morschhauser F, Solal-Celigny P, Thieblemont C, Lamy T, Tilly H, Gyan E, Lei G, Wenger M, Wassner-Fritsch E, Cartron G: Obinutuzumab (GA101) in patients with relapsed/refractory indolent non-Hodgkin lymphoma: results from the phase II GAUGUIN study. J Clin Oncol 2013;31:2920-2926.
35 Morschhauser FA, Cartron G, Thieblemont C, SolalCeligny P, Haioun C, Bouabdallah R, Feugier P, Bouabdallah K, Asikanius E, Lei G, Wenger M, WassnerFritsch E, Salles GA: Obinutuzumab (GA101) monotherapy in relapsed/refractory diffuse large B-cell lymphoma or mantle-cell lymphoma: results from the phase II GAUGUIN study. J Clin Oncol 2013;31:2912-2919.

36 Sehn LH, Goy A, Offner FC, Martinelli G, Friedberg J, Lasserre SF, Fine G, Press OW: Randomized phase II trial comparing GA101 (obinutuzumab) with rituximab in patients with relapsed CD20+ indolent B-cell non-Hodgkin lymphoma: preliminary analysis of the GAUSS study. Blood 2011;118:124-1124.

37 Morschhauser F, Salles G, Cartron G, Crump M, Birkett J, Carlile D, Sehn L: Dose selection for phase III studies of the monoclonal anti-CD20 antibody obinutuzumab (GA101): a rational approach. Haematologica 2011;96:390, abstr 0935 .

38 Zelenetz AD, Mobasher M, Costa LJ, Flinn I, Flowers CR, Kaminski MS, Sandmann T, Trunzer K, Vignal C, Forero-Torres A: Safety and efficacy of obinutuzumab (GA101) plus CHOP chemotherapy in first-line advanced diffuse large B-cell lymphoma: results from the phase 2 GATHER study (GAO4915g). Blood (ASH Ann Meet Abstr) 2013;122:1820.

39 Flynn JM, Byrd JC, Kipps TJ, Boxer M, Kolibaba KS, Tyson N, Hirata JH, Sharman JP: Obinutuzumab (GA101) $1000 \mathrm{mg}$ vs. $2000 \mathrm{mg}$ in patients with chronic lymphocytic leukemia (CLL): results of the phase 2 GAGE (GAO4768g) trial. J Clin Oncol 2014;32.

40 Brown JR, O’Brien S, Kingsley CD, Eradat H, Pagel JM, Lymp J, Hirata J, Kipps TJ: Safety and efficacy of obinutuzumab (GA101) with fludarabine/cyclophosphamide (G-FC) or bendamustine (G-B) in the initial therapy of patients with chronic lymphocytic leukemia (CLL): Results from the phase 1b GALTON trial (GAO4779g) Blood (ASH Ann Meet Abstr) 2013;122:523.

41 Goede V, Fischer K, Busch R, Engelke A, Eichhorst B, Wendtner CM, Chagorova T, de la Serna J, Dilhuydy MS, Illmer T, Opat S, Owen CJ, Samoylova O, Kreuzer KA, Stilgenbauer S, Dohner H, Langerak AW, Ritgen M, Kneba M, Asikanius E, Humphrey K, Wenger M, Hallek M: Obinutuzumab plus chlorambucil in patients with CLL and coexisting conditions. N Engl J Med 2014;370:1101-1110.

42 Goede V, Fischer K, Engelke A, Schlag R, Lepretre S, Casado Montero LF, Montillo M, Fegan C, Asikanius E, Humphrey K, Fingerle-Rowson G, Hallek M: Obinutuzumab as frontline treatment of chronic lymphocytic leukemia: Updated results of the CLL11 study. Leukemia 2015 [Epub ahead of print].

43 Freeman CL, Dixon M, Houghton R, Humphrey K, Fingerle-Rowson G, Kreuzer K-A, Engelke A, Hallek M, Goede V: Risk factors associated with the development of infusion-related reactions in patients with chronic lymphocytic leukaemia treated with anti-CD20 monoclonal antibodies: analysis of the CLL11 study dataset. Blood (ASH Ann Meet Abstr) 2014;124:3339.
44 Roche media release: Roche's phase III study of Gazyva/Gazyvaro showed significant benefit in refractory indolent non-Hodgkin's lymphoma, Basel, 4 February 2015 (www.Roche.Com/media/store/releases/med-cor2015-02-04.Htm, accessed 2 March 2015).

45 Bosch F, Illmer T, Turgut M, Cortelezzi A, Lasserre SF, Truppel-Hartmann A, Leblond V, Foà R, Stilgenbauer $\mathrm{S}$ : Preliminary safety results from the phase IIIb green study of obinutuzumab (GA101) alone or in combination with chemotherapy for previously untreated or relapsed/refractory chronic lymphocytic leukemia (CLL) Blood (ASH Ann Meet Abstr) 2014;124:3345.

46 Jak M, van Bochove GG, Reits EA, Kallemeijn WW, Tromp JM, Umana P, Klein C, van Lier RA, van Oers MH, Eldering E: CD40 stimulation sensitizes CLL cells to lysosomal cell death induction by type II anti-CD20 mAb GA101. Blood 2011;118:5178-5188.

47 Kohrt HE, Sagiv-Barfi I, Rafiq S, Herman SE, Butchar JP, Cheney C, Zhang X, Buggy JJ, Muthusamy N, Levy R, Johnson AJ, Byrd JC: Ibrutinib antagonizes rituximab-dependent NK cell-mediated cytotoxicity. Blood (ASH Ann Meet Abstr) 2014;123:1957-1960.

48 Davis C, Stepanchick E, Syed K, Axel A, Hall B, Sasser $\mathrm{K}$, Balasubramanian S: Effects of ibrutinib on rituximab and GA-101 induced antibody-dependent cell cytotoxicity (ADCC) in lymphoma cells in vitro. Blood (ASH Ann Meet Abstr) 2014;124:3117.

49 Flinn I, Brunvand M, Dyer MJS, Hillmen P-, Jones J, Lymp J, Elhamy M, Vosganian G, Huang J, Kipps TJ: Preliminary results of a phase lb study (GP28331) combining GDC0199 (ABT199) and obinutuzumab in patients with relapsed/refractory or previously untreated chronic lymphocytic leukemia. Blood (ASH Ann Meet Abstr) 2014;124:4687.

50 Morschhauser F, Salles G, Le Gouill S, Tilly H, Thieblemont C, Bouabdallah K, Cartron G, Houot R: A phase Ib study of obinutuzumab combined with lenalidomide for relapsed/refractory follicular B-cell lymphoma. Blood (ASH Ann Meet Abstr) 2014;124:4458.

51 Gagez AL, Cartron G: Obinutuzumab: a new class of anti-CD20 monoclonal antibody. Curr Opin Oncol 2014;26:484-491.

52 Dyer M, Grigg A, González Díaz M, Dreyling M, Rule S Lei G, Wassner-Fritsch E, Fingerle-Rowson G, Marlton $\mathrm{P}$ : Obinutuzumab (GA101) in combination with $\mathrm{CHOP}$ (cyclophosphamide, doxorubicin, vincristine and prednisone) or bendamustine for the first-line treatment of follicular non-Hodgkin lymphoma: final results from the maintenance phase of the phase Ib GAUDI study. Blood (ASH Ann Meet Abstr) 2014;124:1743. 